\title{
ŞiDDETE GÜLMEK: GeLENEKSEL TÜRK TIYATROSUNDA ŞidDET Ve Mizah
}

\author{
TO LAUGH AT ViOLENCE: \\ VIOLENCE AND HOMOUR \\ IN TRADITIONAL \\ TURKISH THEATRE
}

özet

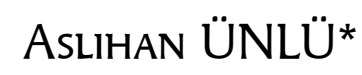

Șiddet, kültürel ve dönemsel farklılıklarla tanımı değișen bir olgudur. Illk çağlardan itibaren, kutsal ve oyun ile de yolu kesișir. Kutsal, oyunda ciddi ve komik biçimlerde ortaya çıkarken toplumdaki kötü güçler dışsallaștırılıp arındırılır. Köy seyirlik oyunları, șenliklerdeki gösteriler, meddah hikayeleri, karagöz ve ortaoyunu șiddetin konu, dil, hareket gibi pek çok yolla dışavurumunu içerir. Oyunların bu özelliği çok kültürlü ve çok çatıșmalı Osmanlı'da șiddetin sağıltılmasına katkıda bulunur. Seyircinin, ritüellerde olduğu gibi güçlenerek oyun sırasında kuralları bozulmuș günlük yașama yeniden uyumlanmasını sağlar.

\section{Abstract}

Violence is a phenomenon whose description changes parallel to cultural and periodical differences. From the first ages on, its route also intersects with the holy and the play. Whereas the holy appears in serious and comic forms, the evil powers in the society are externalized and bowdlerized. Village performance plays, performances in Otoman festivals, Meddah's stories, Karaghioz and Ortaoyunu embrace expressions of violence through many different means such as subject matter, language and movement. This property of plays contributes to the uncoiling of violence in the multicultural Ottoman society which is a settlement of great dispute. It helps the audience get stronger as in the rituals and in this way harmonize with the daily life whose rules are broken throughout the play.

\footnotetext{
* Yard.Doç.Dr., Dokuz Eylül Üniversitesi, Güzel Sanatlar Fakültesi, Sahne Sanatları Bölümü
} 
1 Kudret EMIROĞLU, Suavi AYDIN, Antropoloji Sözlüğü, Bilim ve Sanat Y., Ank., 2003, s.767.

2 Bkz.; Semra SOMERSON, "Șiddetin İki Yüzü”, Cogito-Șiddet, Y.K.Y., sayı 6-7, kıș bahar 1996, s.41-50.

3 J. HuizingA, Homo Ludens, çev:M.A.Kılıçbay, Ayrıntı Y., İst.,1995.

${ }^{4}$ A.g.e., s.68.

${ }^{5}$ René GIRARD, Șiddet ve Kutsal, Çev: Nemciye Alpay, Kanat Y., Est., 2003., s. 454 .
A ntropologlar, kültür bilimcileri kültürel yașamın süreçlerini incelerken iki olguyla hep karșılașmak, onları çözümlemek zorunda kalmıștır. Bunların birisi oyun, diğeri ise șiddettir. Doğumdan ölüme uzanan ve doğanın ritmine benzeyen yașamın her așamasında bu iki olgu iç içe geçmekte, ayin ve ritüeller șiddetin oyuna, oyunun șiddete dönüșümünü göstermektedir. Burada söz konusu olan kișisel saldırganlığın ve öfkenin sonucu ortaya çıkan "kaba" șiddet değildir. Șiddetin kültürler arası değerlendirmesini yapan David Riches, Anglosakson kültüründe șiddetten söz edildiğinde, ölçütün devlet tarafından belirlendiği fiziksel zararın ve gayri meșruluğun anlașıldığını söyler. Oysa "antropologlar șiddetin bireysel değil kolektif, toplum dıșı veya karșıtı değil toplumsal olduğunu göstermiștir"1. Șiddet pek çok toplumda kutsal olanın ve törenlerin ayrılmaz bir parçasıdır. Günlük yașamdaki șiddetten, yani zararlı, yıkıcı șiddetten kaçmak için bunun oyunlaștırıldığı, böylece sağaltıcı, yararlı șiddete geçildiği de görülmektedir. Hatta uluslararası savașlar, kitlesel imha silahları, sokak çatıșmaları dikkate alındığında çağımızın Batı dünyasındaki "ölçüsüz șiddet terör"e karșı, Batılı olmayan toplumlarda savaș, kan davası, kavga ya da ritüeller dolayımıyla yașanan șiddetin "ölçülü șiddet" olduğu vurgulanır. ${ }^{2}$ Kültürden kültüre ya da aynı kültürde değișik dönemlerinde șiddetin tanımı, amacı ve yönelimini de değișir.

İnsanın, bitimli, tekdüze yașamı ile sonsuz bir döngü içinde olan doğayı ve tanrılar düzenini uzlaștırmak için bulduğu "oynama" çözümü, avın, günlük yașamın zorluklarının, doğa olaylarının taklidi ile bașlamıș, ayin ve ritüellerle devam etmiștir. İbadeti bir simgeleștirme, bir dramatik temsil olarak gören Huizinga, kültürün ilk așamalarından itibaren oyunla geliștiğini, bașlangıçtan beri oyun biçiminde doğan ve oynanan bir șey olduğunu iddia eder. ${ }^{3}$ Zamanla geri plana çekilen oyunsal nitelik, günümüzün toplumsal çatıșmalarında, kültürel faaliyetlerinde, hatta en ciddi alanlar olan uluslararası hukuk ve ticarette gördüğümüz gibi yeniden "bireyi de kitleyi de her an devasa bir oyunun sarhoșluğuna"4 sürükleyebilecek bir șekilde, kültürel alanlar içinde varlığını sürdürmektedir. René Girard ise Huizinga'nın önermesini tersine çevirir. Kutsal olandaki oyunu değil, oyunlarda dönüșüme uğramıș ama varlığını hep hissettiren kutsalı arar. ${ }^{5}$ Girard, ayini dramatik bir 
bütün, bir tür sanat yapıtı olarak değerlendiren Turner’a değinerek tiyatroda oynanan dramın da " bir tür ayinden, dinsel görüngünün karanlık bir yenilenmesinden ibaret" olabileceğine dikkat çeker. ${ }^{6}$ Girard'ın çalıșmasına adını veren ikilik "șiddet ve kutsal”, bir bașka olgu olan oyunla hep kesișir.

Ancak kutsalın da oyunun da ortaya çıkıș biçimi her zaman "ciddi" değildir. Nasıl ki tanrılar hem ciddi hem komik olabiliyorsa, oyunun da "ciddi" ve "komik" yansımaları aynı kutsallık kökeninden kaynaklanıp benzer amaçlara, sadece farklı yöntemlerle hizmet eder. Ayinler sırasında toplulukların içlerinden atıp rahatlamak istedikleri duygular, itkiler bir yandan da alay etme, gülünçleme șeklinde ortaya çıkar. Karnavallarda hiyerarșilerin bozulmasında, bașlangıcı çok eskilere giden ve pek çok kültürde görülen kralın ikamesi olan soytarılarda, Dionysos'da bulduğumuz komik öge, kutsal olanın oyuna yansıması olarak belki de dramdan daha çok varlığını sürdürür. Girard, kurbandan ya da bunun bașka bir biçimi olan sürgün etmeden söz ederken "toplumsal dıșlamanın yumușatılmıș, gündelik ve sıradan kılınmıș biçimleri günümüzde hala uygulanıyor; genellikle de gülünçlük temelinde" der. Riches de "șaka ya da ritüel edimler de ya ciddi șiddet "tehditleri" olarak tasarlanmıștır ya da söz konusu toplumda șiddete bașvurmanın ya da bașvurmaya hazırıklı olmanın tașıdığı değerin oyun biçimindeki simgeleridir"8 derken șiddettin komik olan yoluyla da dıșsallaștırıldığından söz eder. Mizahın her zaman bașkaldırıcı bir yönü olmuștur. Bu nedenle Antik Yunan'da ortaya çıkan dram Dizonizyak etkinin Apolloncu güç tarafından kontrol altına alınması olarak da değerlendirilmiștir. Günlük yașamın hiyerarșik ve kurallarla belirlenmiș, sabitlenmiș yapısı mizah yoluyla parçalanırken kișinin ya da toplumun kendinde gördüğü ama bastırdığı ya da ortaya çıkmasını istemediği kötü güçlerin bașkasına gülme yoluyla dıșarı atıldığını görebiliriz. "Komik unsur, bastırılanı söküp atmasa da, onun ağırlığını azaltır, böylece bir katarsis etkisi yaratır." 9

Sert doğa koșulları, insanın barınmak, karnını doyurmak, yașamda kalabilmek için mücadelesi ilkel topluluklarda doğadan sakınma veya ona egemen olma arayıșını getirmiștir. Günlük yașamın

\footnotetext{
${ }^{6}$ A.g.e., s.421.

7 A.g.e., s. 366.

${ }^{8}$ David RiCHES, "Șiddet Olgusu", Antropolojik Açıdan Șiddet, Çev: Dilek Hattaoğlu, Ayrıntı Y., İst.1998.

9 İrene FENOGLIO, Francois GEORGEON, "Sunuș", Doğu'da Mizah, çev: Ali Berktay, Y.K.Y., İst., 2000, s.9.
} 
korku ve șiddet dolu yönleri ayinlerde ve bunların oyunsu yansımalarında da kendini bolca gösterir. Bu dönemlerin animistik inançları var olan, canlı cansız her șeye bir ruh atfetmekte, canlılar skalası yapıp insanı onun en üst basamağına yerleștirmemektedir. Bu nedenle avcılık bile bir tür rıza ișidir. Hayvanın rızasını almak için özel bir tören düzenlemeden ya da onu postlara bürünüp yanıltmadan yapılan av, soyun bașına belaların gelmesine neden olabilir. Bireyin toplumsallașmasında bir sınav olan erginlenme törenleri de korku ve șiddetin bileșimidir ve bireyi bunlara karșı așıı hale getirirken, topluluğun șiddetinin dıșa vurulması, savușturulması ișlevini de yüklenir. Benzer ritüeller, göçebe așiretlerde biçim değiștirerek halen yașamaktadır. Örneğin, Tahtacı düğünlerinde damadın yüzünün boyandığı, üzerine çamurlu su döküldüğü, gün boyunca arkadașlarının șakalarına maruz kaldığı, hırpalandığı, hatta üzerine oturarak içki içildiği görülür. ${ }^{10}$ Bütün bunlar bir karnaval havasında yapılmakta, genç adam eski kimliğini terk etmekte yeni yașama adım atmakta, bu kimlik değișimi anının getireceği bunalımdan bu yolla kurtarımaktadır. Geçiș ritlerinin genelinde șiddetin aldatılığı, yönünün değiștirildiği, oyun içinde eritildiği görülür.

${ }^{10}$ Bkz.; Handan TÜRKELI, "Tahtacı Düğünü”, Atlas, Sayı 94, Ocak 2001, s.84-98.

${ }^{11}$ Bkz.; Nurhan KARADAĞ, Köy Seyirlik Oyunlar, Türkiye İș Bankası Y., Ank.,1978.
Kökenini ritüellerden alan, büyük çoğunluğunun oyun yapısı doğanın canlanıșı, hayvanların yavrulaması, ya da yağmur yağdırılması gibi doğayı etkilemek ve ondan sakınmak üzerine kurulu olan köy seyirlik oyunlarımızda șiddet ve oyunun bileșimini çok net görebiliriz. Dede, Çoban, Arap, Muhtar gibi oyun kișilerinin kimliğinde ak ve kara güçlerin çatıșması, doğanın ritmine öykünen kahramanların ölme-dirilmeleri, baharın kaybolup yeniden gelmesini anlatan kız kaçırmalar oyunlarda yinelenir. Oyun kișilerinden birinin ya da bir kaçının nedensiz bir șekilde düșüp ölmesi ağıtlarla karșılanırken, ağzına konulan yemiș, para ya da su ile yeniden dirilmesi sevinç nidaları, dans ve türkülerle kutlanır. Bu oyunlarda oyuncuların ya da seyircilerin itilip kakılması, üzerlerine oturulması, değișik gerekçelerle canlarının yakılması sık görülen ve seyredenleri güldüren hareketlerdir.11

Canlıı̆ın kutsanması ve düzenin devamının sağlanması yolundaki ayinler imparatorluk yapısı içinde biçim değiștirerek padișah 
șenliklerine dönüșmüșlerdir. ${ }^{12}$ Padișahların tahta çıkıșı, sultan hanımların evlenmeleri, veliahtların sünnetleri, okula bașlamaları, bir zaferin kazanılması gibi nedenlerle yapılan șenlikler, geçit törenleriyle, hediyeleșmelerle bașlayan, sportif gösteriler, hüner gösterileri, dans ve müziğin yanı sıra dramatik temsillerle devam eden, her kesimden herkesin bir arada eğlendiği yapısıyla ilksel ayinlere çok benzemektedir. Bu șenlikler zorbazların acıya dayanıklılık sınavı vermelerinin yanı sıra eșeklere fișekler bağlayıp yakmak gibi hayvanların acısına gülme türünden șiddet ögeleri de içermektedir. Bu șiddet biçimlerinin en ilginci tiryakilerin afyonun etkisiyle uyukladıkları kahvehanelerden çıkartııp sokaklarda dolaștırılmaları, çevrelerini saran insanların alay ederek, korkutarak onlarla eğlenmeleridir. Bunu, Antik Yunan'da pharmokosların kurban töreninden önce bütün kirleri üzerlerinde toplamaları için halkın arasında dolaștırılmalarına benzetebiliriz. Çevresinden alay, hakaret ve șiddete maruz kalan kurbandan, "kötücül șiddeti üstüne çekerek, ölümüyle bu șiddeti iyicil șiddete, barıșa ve berekete dönüștürmesi”13 beklenmektedir. Tiryakiler de kendi istemleri dıșında șenlik oyunlarına dahil olmakta, kötücül güçlerin dıșa atımının bir aracı yapılmaktadırlar. Tiryakilerdeki tek yönlü alayı çift yönlü saldırıya dönüștüren tulumcular ise ellerindeki tulumlardan halkın üzerine su fıșkırtarak, hem onları eğlendirir hem de șenlik alanının düzenini sağlar. Yüzlerini boyayıp güldürücü danslar yapan soytarıların, sokak komiklerinin alayından, grotesk mizahından devlet büyükleri bile kurtulamaz. Șehzadenin taklidi bile yapılır; gerçi bu oyunun yasaklandığı ama sadrazamın taklidine izin verildiği yabancı gezginlerin notlarında yer alır. Șenliklerde iki tarafın askerlerinin gerçekçi bir biçimde birbirine saldırdığı, çok bașarılı maketler eșliğinde bir kaleyi ele geçirmeye çalıștığı ya da șenlik alanına kurulmuș göllerde kalyonların çatıștığı savaș oyunları da oynanır.

Șiddet ögeleri, daha çok sokağın gerçeğini anlatan meddah hikâyelerinde sıklıkla karșımıza çıkar. Tıfli'nin hikâyelerinde pașa kılığına giren Halepli Türk'e gerçek ortaya çıkınca dayak atıır, padișaha giden ulak saraya paldır kültür girince askerlerden dayak yer. Mahmut Sebüktekin hikâyesinde Șah'ın oğluna görünerek kehanetin gerçekleșmesini sağlayan Mahmut hem oğlanın ölümüne neden olur hem de Șah tarafından yakılarak

${ }^{12}$ A.g.e., s. 421.

${ }^{13}$ R. GiRARD, Ön. Ver., s.133. 
cezalandırılmaktan son anda kurtulur. Derviș Halil hikâyesinde tılsımı elde etmeye çalıșan Hasan Ağa insanları öldürür. Hançerli Kadın așık olduğu gence türlü eziyetler yapar hatta onu öldürmeye çalıșır. Sadabat'ın Ölü Kadınında hem Mihrimah Sultan öldürülmek istenir, hem de bunu planlayan cariye Esma bir kuyunun dibine sallandırılarak ölüme terk edilir. Karısı, kendisine oyun oynamak isteyen ve bir çuvala gizlenen Hacı Vesvese'yi, çuvaldaki keteni ıslatıp dövmek bahanesiyle bir güzel pataklar. Meddah hikâyelerinde șiddeti yansıtan böyle daha pek çok örnek bulunabilir. ${ }^{14}$ Halk hikayelerinde var olan olağanüstüye, kahramanın mertliğine, bağlıı̆̆ına meddahın yer vermediğine, bu hikayelerde șiddet ve vahșetin çok olduğuna dikkati çeken Özdemir Nutku, bunu meddahın anlattığı günlük gerçekliğin acımasızığına bağlar.

"Özellikle XVIII. yüzyıl meddah senaryolarının dünyaSı, herkesin kendi için yașadığı, bașkasını hiç düșünmeden yok ettiği, acımasız, karanlık ve ahlak-dıșı bir dünyadır. Bu dünyada ayakta durabilmek için çıkarcı, günün adamı, ikiyüzlü, dalkavuk, hırsız ve mirasyedi olmak gerekir." ${ }^{15}$

${ }^{14}$ Bkz.; Özdemir NUTKU, Meddahlık ve Meddah Hikayeleri, Atatürk Kültür Merkezi Bașkanlığı Y., Ank., 1997.

${ }^{15}$ A.g.e., s. $95-96$
Benzer biçimde karagözün hayal perdesi de İstanbul'un günlük yașam gerçeğini, mahalle yașantısı, gezinti yerleri, düğünler, iș hayatıyla gözler önüne serer. Ancak meddahın tek kișilik anlatısına karșılık burada perdenin ardındaki (bazen yardımcıları olsa da) tek ustanın elinde pek çok tasvir canlanır. Bașta diğer tiplerin aksine belirli bir cemaate gönderme yapmaksızın toplumun geneline yayılmıș olan okumuș-cahil, kurnaz-saf vb. karșıtlıkları sergileyen eksen kișiler Karagöz ve Hacivat olmak üzere, kadınlar, özürlüler, abdallar, mahallenin namus bekçileri, tüccarlar, yolu mahalleye düșen her kesimden insan sergilenir. Karagözde perdenin yarattığı yanılsamadan ve bu yanılsamanın kolayca bozulabilmesinden yola çıkılarak mizahın grotesk anlatımı diğer tüm geleneksel Türk tiyatrosu türlerinden daha üst boyuta ulașır. Meddahta pek de yer bulmayan olağanüstülükler, cadılar, büyücüler, tekin olmayan yerler kimi zaman fasılların konusu olmasına karșın, karagözün çoğunlukla milletler ve inançlar çeșitliliğine sahip İstanbul'daki çatıșmaları yansıttığını söyleyebiliriz. Burada bolca kullanılan mizah yöntemlerinden biri de vurma, vurușma, 
Ölme, öldürme, ölüp-dirime vb. biçimlerde aksiyon ve dile yansıyan șiddettir. "Perdenin zalim mizahı" İstanbul'daki yașam koșullarının bir yansımasıdır aslında. "istanbul'da (...) cemaatler de sürekli bir rekabet halinde görülüyor. Bu rekabet meslek zümreleri arasında iktisadi bir mücadele olarak belirdiği gibi, doğrudan doğruya kaba güce dayanan saldırılar ve kanlı isyanlar olarak da ortaya çıkıyor."16

François Georgeon, Osmanlı'nın farklı dini, etnik, yöresel grupların bir tür iletișim ve aralarındaki çatıșma doğurabilen farklıııların sağaltılma biçimi olan, kendiyle alay etme üzerine kurulu halk mizahından, Batılılașma ile birlikte gelișen tek bir "batıı" kimlik üzerinden kurgulanan, bu kimliğin kendinden önceki gülme biçimleriyle ve diğerleriyle alay eden, öğretici mizaha dönüșmesini incelediği yazısında, yazının bașlığına da yansıyan temel soru șudur? : "Tarihi esas olarak dramlarla dolu bir imparatorlukta gülmekten nasıl söz edilebilir?" Georgeon sorusunu yanıtlarken sadece Osmanlı'da değil tüm imparatorluklarda șiddete paralel, hatta bu șiddetin egemenlik iddiasına dayanan bir gülmecenin var olduğuna dikkati çeker. Georgeon'un aktardığına göre, Batıılașma sürecinde mizahın zararlarının tartıșıldığı, Matbuat Müdürlüğündeki bir toplantıda aklıselim sahibi bir müdür "Dünyada komedya ile mizah kalkarsa, fenalığı tepelemek için elimizde silah kalmaz" der. ${ }^{17}$

Gerek halk adamı Karagöz ile okumuș Hacivat arasındaki temel mizaç farklılı̆ııın, gerekse Rum, Kürt, Laz, Çelebi, Frenk, Ermeni, Yahudi, Kastamonulu, Hırbo vb. etnik, dini bölgesel cemaatler arasındaki tavır, anlayıș ve yașayıș farklıı̆ının așılması, sokaktaki çatıșmanın perdede gülünecek bir șeye dönüștürülmesi söz konusudur burada. Zaten karagözün ve yeni yeni olgunlașmıș ortaoyunun sonunu getiren Batı etkisindeki tiyatronun tanınıp sevilmeye bașlaması kadar, milliyetçilik hareketleri ve Balkanlar'daki karıșıklıklarla birlikte toplumsal çeșitliliğin artık üzerine mizah yapılacak bir halinin kalmamasıdır. Cumhuriyet ile birlikte gelen, kimilerine göre millet bilincinin gerçekleșmesi için zorunlu, kimilerine göre ise bir dayatma olan tek kimliklilik bu süreci tamamlar. İçine dahil olmaya çalıștığımız modern dünya-

\footnotetext{
${ }^{16}$ Mahir ȘAUL, "Taklitler Güldürüsü ve Cemaatler Toplumu Karagöz Mizahı Üzerine Bir Deneme", Boğaziçi Üniversitesi Halkbilim Yıllığı, 1975, s.138.

${ }^{17}$ Bkz.; François GEORGEON, "Osmanlı İmparatorluğu'nda Gülmek mi?”, Ed. I. FENOGLIO- F. GEORGEON, Doğu'da Mizah, çev: Ali Berktay, Y.K.Y., İst., 2000, s.79-102.
} 
nın insanın özelliği özelliksizliktir. Bu dünyada "her șey birbirinin yerine geçebilir, hiçbir șeyin değeri yoktur. Bu, dünyanın büyüsünden arındırıması ya da karakterin devalüasyonudur; insan ile dıș dünya arasına mesafe konması ve ortak yașamın tutkularının boșaltılması demektir." ${ }^{18}$ Herkesin birbirine benzemesi, herkesin ortak bir paydada toplanması ilk bakıșta çatıșmaları dindirecek bir șeymiș gibi görünebilir ama tam tersi olur. Çünkü farklııklar kișilere ait olunacak ve içinde gündelik yașamın açmazlarına da en genel hukuki sorunlara da çözüm bulacağı kendine özgü kuralları verdiği gibi, cemaat aracılığıyla bir benlik duygusu da verir. Farklılık, öteki ile kurulan ilișki, kișinin kendini kurmasını da sağlar. Girard, Yunan tragedyasında da ilkel dinlerde de șiddetin, kargașanın farklııktan değil, farklılığın yitiminden kaynaklandığını söyler. "Bu bunalım, insanları her türlü ayırt edici nitelikten, her tür "kimlik"ten yoksun bırakan süreğen bir çatıșmanın içine atar."19 Karagöz ve ortaoyunu ise mizahını tam da bu farklılıklar üzerinden kurar. Bu nedenle de perdede dövüșen, birbirini anlamayan, birbirine zulüm eden insanlar, öncelikle ötekinin karșısında kendi var olușunu sonra da ötekiyle bir arada olmanın koșullarını yaratır. Girard'ın ayinler üzerine yaptığı değerlendirme öznesine geleneksel tiyatromuz ve özellikle de karagöz oyunları konularak yeniden okunabilir rahatlıkla: "Düzenleyen, barıș getiren, uzlașma sağlayan oybirliği, her zaman kendi tersinden, yani bölen, düzleyen ve yıkan șiddetin doruğa ulașmasından sonra geliyor. (...) Topluluğun oybirliğine yeniden kavușması, kısa ve dehșet verici bir "zıtların birliği"nde gerçekleșiyor."20

${ }^{18}$ Nuri BiLGiN, Kimlik Sorunu, Ege Y., İzm.,1994, s.46.

${ }^{19}$ R. Girard, Ön. Ver., s.70.

${ }^{20}$ A.g.e., s. 161 .

${ }^{21}$ A.g.e, s.11.

Oyunlarda kahramanın dövülmesi, öldürülmesi, parçalarına ayrılması bir tür kurban edimidir. "Kurban edimi öncelikle, anlașmazlıkları, rekabetleri, kıskançlıkları, yakınlar arası kavgaları ortadan kaldırmak, topluluk uyumunu yeniden kurmak, toplumsal birliği güçlendirmek iddiasındadır." ${ }^{1}$ Toplumda var olan anlașmazlıkların kurbanda toplanıp giderilmesi, böylece topluluğun kısmi bir arınma, doygunluk yașaması, burada kahramanın komik bir biçimde dil anlașmazlığına düșmesi, dayak yemesi, büyüsel etkilerle çarpılması ya da oyuna getirilip alașağı edilmesi yoluyla olur. 
Karagöz en bașta arkadașı Hacivat ile daha sonra da ișlettiği yere gelen ya da durum gereği mahallede karșılaștığı tiplerle vurușur. Özellikle Karagöz'ün her sözü sonrası Hacivat'a vurması karakteristik hareketidir. Karagöz'ü psiko-sosyal açıdan ele alan Sabri Esat Siyavușgil, Karagöz'ün önüne gelene vurmasında onun inatçı, șekilci efendilere ders veren, hataları yüze vuran kimliğini görür; Karagöz diğerlerinde bulunmayan "hakiki bir efendi serbestliğiyle hareket eder”. Özellikle Hacivat ile yarattığı bu kimlik karșıtlığı tasvirlerin durușuna, hareket özgürlüklerine de yansır. "Hacıvad'ın iki eli de daima göğsüne yapıșık durur. Onun böyle söz ve formül mekanizmi içinde kaskatı kesilmesine mukabil Karagöz'ün tabiate uygun dinamizmi, iki karakter arasındaki derin tezadı tebarüz ettirir."22 Karagöz de bu hareket özgürlüğünü, eline fırsat geçirdiği her an sonuna dek kullanacaktır.

Bütün mukaddimelerde, yani oyun giriș bölümünde iki eksen karakter vurușmalı bir dostluk sergilerler. ${ }^{23}$ Bir eğlence, bir dost arayan Hacivat'ın ısrarlı çağrısı, rahatı bozulan Karagöz tarafından dayak ile karșılanır. Hacivat'ın perdeden kovulmasının ardından yerlere yayılan Karagöz bazen "Of! Öldüm, bayıldım, mușmula gibi yerlere yayıldım!" deyip ağrıyan yerlerini sıralarken, bazen de "Seni gidi beni bilmez, hiç kimseden utanmaz, asla borcuna para vermez, dolandırıcı herif seni! Seni iki bacağından tuttuğum gibi sallar sallar Tekfurdağı'na kadar fırlatırım, alçak herif, Benimle ne alıp veremiyorsun, a mum bacaklı kerata" diye verip veriștirir. İki eksen kișinin oyunun asıl konusundan bağımsız, kendi kișilik özelliklerini sergiledikleri, atıșarak mizah yarattıkları muhavere kısımlarında ve fasılların kimi yerlerinde de dayak eksik olmaz. Muhaverelerin bașlaması yine vurușmaya dayanır, Hacivat'ın iletișim kurma çabası Karagöz'ün öfkesi ile karșılanırsa da, dayağa bir son vermezlerse oyuna geçemeyeceklerini bilirler ve nasıl birden bașladılarsa vurușmaya birden de dostluğa/muhabbete geçerler:

$\begin{array}{ll}\text { HACIVAT } & \text { (Gelir.) Vay efendim! Akșam-i șerîfler ha- } \\ & \text { yırlar olsun! } \\ \text { KARAGÖZ } & \text { Râriha-i kerîne burnuna dolsun! (Vurur.) } \\ \text { HACIVAT } & \text { Bendenize vurmanın vechi? } \\ \text { KARAGÖZ } & \text { Pek büyüktür Eleni Hanımın ferci! } \\ & \text { (Vurur.) }\end{array}$

\footnotetext{
${ }^{22}$ Sabri Esat SiYAVUȘGiL, Karagöz (Psiko-sosyal Bir Deneme), Maarif Mat., Ank.,1941, s.157.
${ }^{23}$ Karagöz metinleri için bkz.; Cevdet KUDRET, Karagöz I-II-III, Y.K.Y., İst., 2004.




\section{ASLIHAN ÜNLÜ}

$\begin{array}{ll}\text { HACIVAT } & \text { Bana vurmanızın sebebi? } \\ \text { KARAGÖZ } & \text { Manavındır, bırak yerine sepeti! (Vurur.) }\end{array}$

\begin{tabular}{|c|c|}
\hline HACIVAT & Bendenize vurmanızda bâis? \\
\hline KARAGÖZ & $\begin{array}{l}\text { Bıyığına osursun ahırdaki kör seyis. } \\
\text { (Vurur.) }\end{array}$ \\
\hline HACIVAT & Vurmanızdan aksâ-yi murâd? \\
\hline KARAGÖZ & Aksaray'da murtad babandır! (Vurur.) \\
\hline HACIVAT & Ne hakkın var beni dövmeye? \\
\hline KARAGÖZ & $\begin{array}{l}\text { Yalnız dövmek değil, șimdi bașlayacağım } \\
\text { sövmeye! (Vurur.) }\end{array}$ \\
\hline HACIVAT & $\begin{array}{l}\text { Seni idbâr köpek seni! } \\
\text { (Hacivat da Karagöz'e vurur.) }\end{array}$ \\
\hline KARAGÖZ & Seni müflis pezevenk seni! (Vurur.) \\
\hline HACIVAT & Seni arsiz herif seni. (Vurur.) \\
\hline KARAGÖZ & Seni yüzsüz herif seni! (Vurur.) \\
\hline HACIVAT & Böyle dayakla vakit mi geçireceğiz. \\
\hline KARAGÖZ & Artık dayağın hızı geçti. ${ }^{24}$ \\
\hline
\end{tabular}

Fasıllarda yaptığı iș ya da gözettiği-gözetlediği yer gereği değișik cemaatlerin temsilcileriyle karșılașan, onlarla bir türlü iletișim kurmayı bașaramayan Karagöz kimi zaman dayak atmaya kimi zaman da yemeğe devam eder. Aslında burada iki tür vurușma söz konusudur. Hem kaba bedensel, hem de anlașmazlık üzerinden dilsel. Șairlik/așıklar faslında șiirlere ölçüye uygun ama anlamsız ya da çarpıtılııs sözlerle karșılık vererek atıșan Karagöz'ün "Var mı bașka dayak yiyecek? Kendine güvenen gelsin" diye meydan okumasına șiirleriyle karșılık veren taklitler Așık Hassan, Tiryaki, Kabakçı Arap, Beberuhi hep dayak ile uğurlanır perdeden. Bazen de dayak yiyen Karagöz'dür. Tahmis'te kahve dövmeye çalıșan Arap'ın tokmağını yer kafasına. Kanlı Kavak faslında iki Arnavut Karagöz'e beș yüz değnek vuracaklardır ama her seferinde sayıyı șașırıp baștan bașlarlar.

Vurușma-dayak, atıșma konusunda Karagöz'le en çok yarıșan tipleme Karagöz'ün Karısı'dır. Șirretlikte, ahlaksızlıkta, küfürbazlıkta birbirlerine karșı sınır tanımazlar. Hekimlik fasında kocasından dayak yiyen ve bağırıp ağlayan Karagöz'ün karısı, Havicat'ın araya girmesine "Belki benim canım dayak yemek istiyor" diyerek itiraz eder: Karısının itirazını destekleyen Karagöz'ün vurușları bu 
kez kavgaya karıșan Hacivat'a yönelir. Ancak aynı fasılda Karısı Karagöz'den intikamını fazlasıyla alacaktır. Ağasının dili tutuımuș kızına doktor arayan Bayram Ağa'yı Karagöz'ün çok iyi bir hekim olduğuna ama iyice bir dövülmedikçe hekimliğini kabullenmediğine ikna eder. Bu sayede fasıl boyunca değișik kișilerden bol bol dayak yiyen Karagöz, en sonunda aklını kullanarak kızı sahte hastalığından kurtardığı gibi para da kazanır.

Karagöz kendisiyle bile dövüșür. Bahçe faslının ara muhaveresinde karșısında ikinci ve o ne söylerse tekrar eden bir Karagöz daha bulunca çileden çıkar ve onu perdeden kovalayana dek dövüșür. Bu ara muhaverenin ardından gelen muhavere de zaten Karagöz'ün yanlıșlıkla karanlık, ahıra benzettiği bir yere girmesini ve oradaki yangını gerçek sanıp ortalığı birbirine katmasını anlatır. Aslında girdiği yer tiyatro, yangın bir hayaldir ve seyircilerden bir temiz dayak yer oyunu bozduğu için.

Bazen de verilen zarar vurușmadan öteye gider. Ya kutsal olana saygısızca davranan Karagöz ve Hacivat elleri ayakları çarpılarak (Kanlı Kavak), eșeğe ve keçiye dönüștürülerek (Cazular) cezalandırılır ya da Eczane faslında olduğu gibi șiddet iyice grotesk bir hal alır. Bu fasılda, diğer pek çok fasılda olduğu gibi yeteneği ve bilgisinin olmadığı bir alanda, eczacılıkta iș tutmaya çalıșan Karagöz tedavi için kendisine bașvuran taklitlere etmediğini bırakmaz. Kerpetenle Yahudi'nin çenesini çıkarır, İhtiyar'ın ise kolunu, bașını kopartır, sonra yerine takmak isterse de ters takar, beceremeyeceğini anlayınca İhtiyar'ın vücudunu tekerlek gibi döndürerek perdeden çıkarır.

Karagöz'de seyirlik oyunların bir uzantısı olarak görebileceğimiz ölüp-dirilme motifine de rastlanır. Canbazlar'da ipe çıkan Karagöz düșüp ölür, tabuta konulur ama daha sonra canlanarak tabuttan fırlayıp kaçar. Salıncak'da Karagöz'ün sallarken düșürüp öldürdüğü Yahudi, tabuta konulur ama o da canlanır, hatta ölü taklidi yapıp Karagöz ile dalga geçerek onu pataklayıp kaçar. Bahçe faslının finalinde ölmekte olan Karagöz, onun kișiliğinde simgeleșen toplumsal nedenlerle dirilmek zorunda kalır. Hacivat onun vasiyetini alırken alacağını vereceğini sorar. Yenikapı'da ye- 
diği karpuzun kabuklarını, Galata'da çorbaya kırdığı yumurtanın kabuklarını alacak olan Karagöz'ün vereceği ise "Bakkala bin beș yüz, kasaba beș yüz, zerzevatçıya altı yüzdür, ekmekçiye bin”dir. Alacak vereceği karșılamamaktadır. Bu yüzden Hacivat'ın "Kalk bakalım, ölmenin sırası değil” demesiyle ayağa kalkar. Yoksul halk adamı Karagöz'ün "ağız tadıyla" ölmesine bile izin yoktur. Kimi oyunlarda Karagöz'ün ölüp dirilmesi bir durum olarak ișlenirken, kimi oyunlarda da ölümden söz edilerek mizah sağlanır. "Peder öldü" muhaveresi bunun iyi bir örneğidir. Sayfalar boyunca ölüm üzerine yanlıș anlamalarla gelișen bu muhaverenin sadece çok kısa bir bölümünü buraya alacağız.

KARAGÖZ Ah, Hacivat, babam hatırıma geldileyin tüylerim diken diken oluyor.

HACIVAT Neden?

KARAGÖZ Neden olacak? Babam öldü.

HACIVAT Nerde gördü?

KARAGÖZ Mahalle kahvesinin önünde rasgelmiș galiba. Alay mı ediyorsun be? Bizim peder sizlere ömür.

HACIVAT Kömür mü? Karagöz, bu tabiatını çok severim; hiçbir șeyin vaktini geçirmezsin. Barı çokça mı idi? Ne kadar aldın bakayım?

KARAGÖZ Herif saçmalıyor galiba. neyi be?

HACIVAT Neyi olacak? Kömürü.

KARAGÖZ Eh, alet-tahmin beș yüz okka olmalı. (...)

KARAGÖZ Ulan sana nasıl lakırdı anlatmalı? Babam, kalıbı dinlendirdi?

HACIVAT Galata'da değirmene mi gitti? Bundan ne çıkar, belki iși vardır.

KARAGÖZ Hayır, giderken haber vermedi de, ona kızdım. Tepelerim, lafa omuz vurma.

HACIVAT Canım sen de doğru dürüst söz söylemiyorsun ki anlayım.

KARAGÖZ Allah Allah! Ulan, en doğrusu, peder vefat etti vefat.

HACIVAT A kardeșim, bunda merak edecek ne

${ }^{25}$ A.g.e., Cilt I, s.356-357. var. Madem ki Vefa'ya gitti, Zeyrek'in alt 
ŞiDDETE GÜLMEK: GELENEKSEL TÜRK TIYATROSUNDA ŞiDDET VE MiZAH

bașında bakla avdette 'dönüște) elbette yakalarsın. ${ }^{25}$

Oyunun bitiși de bașlangıcı gibi vurușmalıdır. Hacivat'ın kurnazlığı yüzünden bașına gelmedik kalmayan ama yine Hacivat'ın yardımıyla güç durumdan kurtulan Karagöz'un öfkesi bașındadır: Genellikle Hacivat'ın geçmiș ola dileğini, "Ölü kargalar gözünü oya" dilekleriyle ve vurușla karșılar. Hacivat'ın "elin ayağın kırılsın" ilenmesine, "kenetlenir yine vururum" ya da "çıkıkçıya sardırır yine vururum" diye karșılık verir. Kurnazlığı, ișbilirliği Karagöz tarafından bozulan Hacivat, yakın durduğu, sürmesini istediği düzenden, düzenin bașındakilerden medet umar ünlü sözlerinde ve böylece de oyunun bittiğini ilan eder: "Yıktın perdeyi eyledin vîrân / varayım sahibine haber vereyim hemân.” Ters-yüz edilmenin sonu gelmiștir, günlük yașam gerçekliğine, kurallarına dönülecektir. Ta ki Hacivat bașına gelecekleri bile bile bir kez daha Karagöz'ün kapısına gelip bir eğlence, bir dost arayıncaya dek. Çünkü, "Hacivat gene de Karagöz'süz edemez. Karagöz onun tamamlayıcısı, bilgisini görgüsünü satacağı kimsedir.”26

Oyun yapısı, fasıl konuları, oyun kișileri Karagöze çok benzeyen ortaoyununda canlı oyuncuların olması hareketlerin daha özgürce kullanımasını getirir. Dayak atma sahneleri burada da bulunmakla birlikte dayak atarmıș gibi yapılır ama gerçekten vurulmaz, karșıdaki de dayak yiyormuș gibi yapar. Daha oyunun bașında Kavuklu ile Kavuklu arkasının, Pișekâr'dan korkması sonucu düșüp yuvarlanmaları ve birbirlerinden kurtulmaya çalıșmalarıyla bașlayan itișip kakıșma da oyunlarda sıkça kullanılmıștır. Karagöz'ün ritüelistik etkileri daha çok tașıması ve bu nedenle de hem cinsellik hem de ölüm gibi konulara daha çok yer vermesine karșılık, ortaoyunu bazı abartılar, soytarılıklar ve hünerlerle eğlendirmeye yöneldiği için her iki ögeye de dolaylı olarak yer verir. Kavuklu'nun kendini korkuyla yerlere atıp yeniden ayağa kalkması, Büyücü ve Büyücü Hoca fasıllarında Kavuklu'nun tipleri dondurması ve sonra da Hoca'nın onları çözmesi bir tür ölüpdirilme sayılabilir.

Karagöz ve Ortaoyunu dil anlașmazlıkları, vurușmalar kadar

${ }^{26}$ Metin AND, Geleneksel Türk Tiyatrosu, Bilgi Y., Ank., 1985, s.474. 
${ }_{27}$ İlyaz BiNGÜL, "Osmanlı-Türk Edebiyatında Bir Devrim: Karagöz", Yıktın Perdeyi Eyledin Vîrân, Y.K.Y., İst., 2004, s.53. oyun-bozma yöntemleriyle de mizah sağlar. Kișilerin, perdenin, olayların iç gerçeği, bütün bunların bir oyun olduğu vurgusuyla tekrar tekrar bozulur. Sadece günlük yașam değil, onun taklidi olabilecek oyun da ters-yüz edilir. "Çoğul dillerin perdede birbiriyle itișip kakıșmasına, birbiriyle çene yarıștırmasına, altta kalmamasına dayalı basit bir olay örgüsü içinde kalarak, sürekli alașağı edilen ciddiyetin ve oyunbozanlığın çatıșmasından oyun doğar." 27 Soytarı efendi ile yer değiștirmiș, efendiden intikam alınmıș, ötekilerle yașamanın zorluğu gülünçleștirilmiș; seyirci hem bu oyunbozanlığın bir parçası olarak sağaltılmıș, hem de günlük yașamın kurallarına, ötekilerle hoșgörü içinde yașamaya bir kez daha hazırlanmıștır. 
ŞiDDETE GÜLMEK: GELENEKSEL TÜRK TIYATROSUNDA ŞIDDET VE MiZAH

\section{Kaynakça}

BOURDIEU, Pierre (1984) Distinction. Cambridge: Harvard University Press.

AND, Metin (1985) Geleneksel Türk Tiyatrosu, Bilgi Y., Ank.

BiLGiN, Nuri (1994) Kimlik Sorunu, Ege Y., Izm.,1994, s.46.

BINGÜL, Ilyaz (2004) Osmanlı-Türk Edebiyatında Bir Devrim: Karagöz, Yıktın Perdeyi Eyledin Vîrân, Y.K.Y., İst.

EMiROĞLU, Kudret - AYDIN, Suavi (2003) Antropoloji Sözlügü, Bilim ve Sanat Y., Ank., s.767.

FENOGLiO, Irene - GEORGEON, Francois (2000) Sunuș, Doğu'da Mizah, çev: Ali Berktay, Y.K.Y., İst., s.9.

GEORGEON, François (2000) Osmanlı Imparatorluğu'nda Gülmek mi?, Ed. I. FENOGLIO- F. GEORGEON, Doğu'da Mizah, çev: Ali Berktay, Y.K.Y., ist.

GIRARD, René (2003) Șiddet ve Kutsal, Çev: Nemciye Alpay, Kanat Y., Est., s.454.

HUIZINGA, Johan, (1995) Homo Ludens, çev: M.A.Kılıçbay, Ayrıntı Y., ist. KARADAĞ, Nurhan (1978) Köy Seyirlik Oyunlar, Türkiye iș Bankası Y., Ank.

KUDRET, Cevdet, (2004) Karagöz I-II-III, Y.K.Y., Ist.

NUTKU, Özdemir (1997) Meddahlık ve Meddah Hikayeleri, Atatürk Kültür Merkezi Bașkanlı̆̆ı Y., Ank.

(1972) IV. Mehmet'in Edirne Șenlikleri, T.T.K. Y., Ank.

RICHES, David (1998) Șiddet Olgusu, Antropolojik Açıdan Șiddet, Çev: Dilek Hattaoğlu, Ayrıntı Y., ist.

SiYAVUȘGiL, Sabri Esat (1941) Karagöz (Psiko-sosyal Bir Deneme), Maarif Mat., Ank.

SOMERSON, Semra (1996) Șiddetin Iki Yüzü, Cogito-Șiddet, Y.K.Y., sayı 6-7, kıș bahar, s.41-50.

ȘAUL, Mahir (1975) Taklitler Güldürüsü ve Cemaatler Toplumu Karagöz Mizahı Üzerine Bir Deneme, Boğaziçi Üniversitesi Halkbilim Yıllığı.

TÜRKELi, Handan (2001) Tahtacı Dügünü, Atlas, sayı 94, Ocak, s.84-98.

$$
\text { ศै\%จ }
$$

